\title{
Locoweed Poisoning in a Northern New Mexico Elk Herd
}

\author{
GARY J. WOLFE AND WILLIAM R. LANCE
}

\section{Abstract}

Locoweed (Oxytropis sericea) poisoning was confirmed in $\mathbf{1 6}$ free-ranging elk (Cervus elaphus nelsoni) from northern New Mexico over a 5-year period, 1977-81. Clinical signs consistently seen were emaciation, weakness, incoordination, muscular trembling, posterior ataxia, lethargy, and visual impairment. Gross morphologic changes included hydrothorax, hydroperitoneum, hydropericardium, meningeal edema, serous atrophy of fat deposits, and anemia. Consistent histological changes were widespread cytoplasmic vacuolation in the parenchyma of most major organ systems. This outbreak of locoweed poisoning coincided with poor range condition exacerbated by subnormal precipitation, and was not considered to be a significant mortality factor in the elk herd. However, locoweed poisoning may significantly affect population dynamics of elk herds restricted to ranges severely infested by locoweed.

There are approximately 300 species of Astragalus and Oxytropis in North America. Only 13 are considered true locoweeds - 8 species of Astragalus and 5 species of Oxytropis, including Oxytropis sericea and Oxytropis lambertii. Locoweed poisoning of domestic livestock historically has been a serious problem on rangelands of the western United States (Kingsbury 1964:305-307). It was first described in 1873 and experimentally reproduced in 1906 (Marsh 1909). Locoweed intoxication in livestock is characterized by habituation, emaciation, depression, and neurological disturbances (Van Kampen and James 1969). Additionally, it may result in abortion, fetal deformities, or weak newborn (James et al. $1967,1969)$. The toxicity of locoweed varies by species, species of animal, locality, and among individual animals (Kingsbury 1964:310, James et al. 1967). All plant parts are poisonous during any stage of growth (James et al. 1968). The toxic principal has not been positively identified, but recent work suggests that in $A$. lentiginosus and Oxytropis sericea it may be an indolizidine alkaloid (Molyneux and James 1982). A general review of locoweed poisoning in livestock is given by Van Kampen et al. (1978).

Published accounts of plant toxicities in wildlife populations are rare. Poisonings of pronghorns (Antilocapra americana) due to locoweed (Astragalus spp.), chokecherry (Prunus melancocarpa), and tarbush (Flourensia cernua) have been reported (Buechner 1950:317-318, Ogilvie 1955, Hailey et al. 1966). Locoweed poisoning was diagnosed in 8 elk from a localized area of southcentral Colorado (Adcock and Keiss 1969). Additional "locoed" elk have been sporadically collected from the same geographic area since 1977 (E. Williams, unpubl. data). Histologic lesions characteristic of locoweed poisoning were experimentally reproduced in a single captive elk by feeding a pelletized locoweed ration over a 141-day

\footnotetext{
Authors are with Vermejo Park Corporation, Raton, N. Mex. 87740 and the Wild Animal Disease Center at Colorado State University, Fort Collins 80524

Financial support for laboratory analysis was provided by Vermejo Park Corporation and the Wild Animal Disease Center, College of Veterinary Medicine, Colorado State University. J.K. Baker, R.G. Daugherty, S.D. Kazmar, W.E. Ferranti, J.K. Lackey and T.J. Rogers assisted with field work, and C.P. Hibler, E.S. Williams, and T.R. Spraker assisted with the pathologic evaluations.

Manuscript received December 7, 1982
}

period (Adcock and Keiss 1969). This paper describes the occurrence of locoweed poisoning in a herd of free-ranging elk in northern New Mexico over a 5-year period, 1977-81.

\section{Study Area}

All elk examined were collected at Vermejo Park, a 199,000-ha ranch on the eastern slopes of the Sangre de Cristo mountains in northeastern New Mexico. Elevation ranges from 1,830 to 3,960 m. Five major vegetation types are represented: grama-buffalo grass, juniper-pinyon woodland, ponderosa pine-Douglas-fir, southwestern spruce-fir, and alpine meadows (Küchler 1964). All of the "locoed" elk were collected from a 10,000-ha area between 2,285 and $2,745 \mathrm{~m}$ elevation (Fig. 1). The topography is characterized by

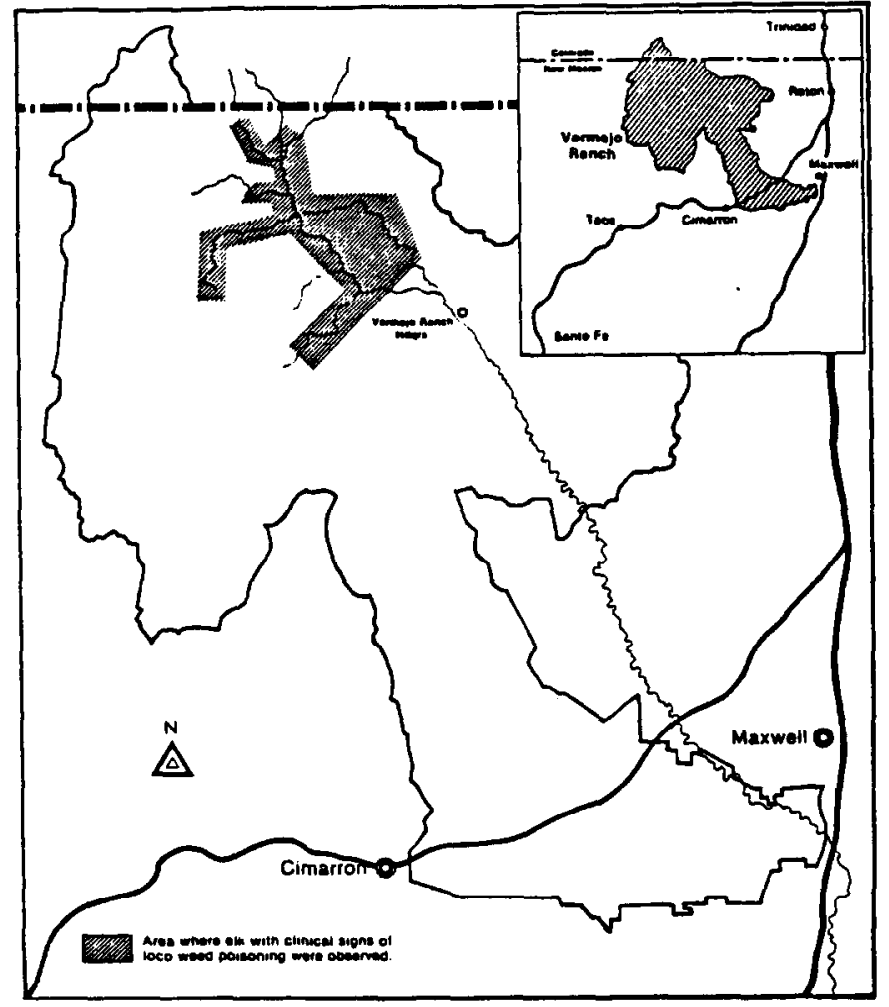

Fig. 1. Vermejo Park, New Mexico.

flat to gently rolling terrain with numerous shallow canyons, rock outcrops, and large open meadows. Primary tree and brush species present are pinyon pine (Pinus edulis), ponderosa pine ( $P$. ponderosa), Douglas-fir (Pseudotsuga menziesii), white fir (Abies concolor), quaking aspen (Populus tremuloides), Gambel oak (Quercus gambelii), true mountainmahogany (Cercocarpus montanus), fragrant sumac (Rhus aromatica), snowberry (Symphoricarpos spp.), currant (Ribes spp.), and bush rockspiraea (Holodiscus dumosus). 
The most abundant forage grasses are blue grama (Bouteloua gracilis), sideoats grama (B. curtipendula), mountain muhly (Muhlenbergia montana), western wheatgrass (Agropyron smithii), beardless pinegrass (Blepharoneuron tricholepis), prairie junegrass (Koeleria cristata), little bluestem (Andropogon scoparius), big bluestem ( $A$. gerardi), Kentucky bluegrass (Poa pratensis), and Arizona fescue (Festuca arizonica). Narrowleaf cottonwood (Populus angustifolia), willow (Salix spp.), mountain alder (Alnus incana), sedges (Carex spp.), and rushes (Juncus spp.) occur in the valley bottoms and riparian areas.

The ranch historically has supported a large cattle herd. Most valley bottoms and riparian areas show evidence of severe past overgrazing. In some areas many preferred species have been replaced by undesirable species such as sleepy needlegrass (Stipa robusta), broom snakeweed (Gutierrezia sarothrae), fringed sagebrush (Artemisia frigida), and locoweed. Oxytropis sericea is the most abundant locoweed at Vermejo Park. Dense stands are found throughout the 10,000 ha delineated in Figure 1. Sparse stands of Oxytropis lambertii and Astragalus spp. are scattered throughout the area.

Elk were extirpated from New Mexico by the late 1890 's. The first reintroduction of elk into the state occurred at Vermejo Park in 1911 (Barker 1976:40). The Vermejo herd, estimated at 4,0006,000 animals, presently constitutes approximately $20 \%$ of New Mexico's elk population (N.M. Dep. Game and Fish, unpubl. data). It is characterized by an old age structure and relatively low recruitment rates (Tables 1,2 ). Hunting is strictly regulated, and

Table 1. Age distribution of 2,105 elk harvested at Vermejo Park, $1974-80$.

\begin{tabular}{cccccc}
\hline & \multicolumn{2}{c}{ Bulls $(N=1,187)$} & & \multicolumn{2}{c}{ Cows $(N=918)$} \\
\cline { 2 - 3 } \cline { 5 - 6 } Age $(\mathrm{yrs})$ & $N$ & $\%$ & & $N$ & $\%$ \\
\hline $11 / 2$ & 58 & 4.9 & & 60 & 6.5 \\
$21 / 2$ & 193 & 16.3 & & 79 & 8.6 \\
$31 / 2$ & 234 & 19.7 & & 91 & 9.9 \\
$41 / 2$ & 203 & 17.1 & & 79 & 8.6 \\
$51 / 2$ & 162 & 13.6 & & 96 & 10.5 \\
$61 / 2$ & 128 & 10.8 & & 77 & 8.4 \\
$71 / 2$ & 88 & 7.4 & & 73 & 8.0 \\
$81 / 2$ & 45 & 3.8 & & 60 & 6.5 \\
$91 / 2$ & 37 & 3.1 & & 62 & 6.7 \\
$101 / 2$ & 20 & 1.7 & & 54 & 5.9 \\
$\geq 111 / 2$ & 19 & 1.6 & & 187 & 20.4 \\
\hline
\end{tabular}

Table 2. Winter calf:cow ratios observed at Vermejo Park, 1975-82.

\begin{tabular}{lcc}
\hline & & $N$ \\
Year & Calves: 100 cows & $\begin{array}{c}N \\
\text { Classified }\end{array}$ \\
\hline 1975 & 41.4 & 973 \\
1976 & 34.0 & 965 \\
1977 & 34.3 & 1,282 \\
1978 & 45.4 & 1,294 \\
1979 & 30.9 & 673 \\
1980 & 22.2 & 1,452 \\
1981 & 45.5 & 1,308 \\
1982 & 40.6 & 1,440 \\
\hline
\end{tabular}

the management goal is maximum production of trophy bulls (Wolfe 1980). Since revenue derived from elk hunting provides a significant portion of the ranch income, the health and general well-being of the elk herd is of paramount importance to overall ranch management (Wolfe 1977).

\section{Methods}

Ranch employees regularly observe elk during performance of their routine activities. Elk exhibiting clinical signs of disease or unusual behavior patterns were brought to the attention of the ranch wildlife biologist. Affected elk were located and shot or, if possible, captured and euthanized by intravenous injection of $T$ 61. Necropsies were performed by the authors or by personnel of the Wild Animal Disease Center. Blood samples were collected when possible. Hematologic values were determined by the Mesa Vista Veterinary Hospital, Raton, N. Mex. Serum chemistry values were determined by the clinical pathology laboratory of the Veterinary Teaching Hospital, Colorado State University. Tissue samples of brain, lungs, heart, intestinal tract, liver, spleen, lymph nodes, thyroid glands, adrenal glands, kidneys, and urinary bladder were collected and preserved in $10 \%$ neutral buffered formalin. Trimmed tissue samples were embedded in paraffin, $6 \mu$ sections cut, and stained with hematoxylin and eosin ( $H$ \& $E$ ). Histological examinations were performed by the junior author at the Wild Animal Disease Center.

Helicopter surveys to determine herd composition were flown each year in January or February (Wolfe 1980). The sex and age structure of the 16 "locoed" elk were compared to herd composition data obtained on the aerial surveys. A Chi-square test was used to test the hypothesis that the sex and age structure of the "locoed" elk was not different $(P>0.05)$ than that of the Vermejo elk herd.

Hematology and blood chemistry were determined for 31 elk trapped at Vermejo Park in 1978 (Wolfe 1980, Wolfe et al. 1982). These blood parameters were assumed to be normal values for the Vermejo elk herd. Student's $t$ test was used to test the hypothesis that blood parameters from "locoed" elk were not different $(P>0.05)$ from those of normal Vermejo elk.

Daily precipitation was recorded at the weather station maintained for the U.S. Weather Bureau at Vermejo Park headquarters. These data were examined in relation to the number of "locoed"elk annually observed on the study area.

\section{Results}

Between 1977 and 1981, 30 free-ranging elk with clinical signs of disease were collected for necropsy. Sixteen had clinical, gross, and histologic signs of locoweed poisoning (Table 3). Several other elk

Table 3. Diagnosis from 30 elk necropsies at Vermejo Park, New Mexico, 1977-81.

\begin{tabular}{lcc}
\hline \hline Diagnosis & $N$ & $\%$ \\
\hline Locoweed poisoning & 16 & 53.3 \\
Elaeophorosis & 7 & 23.3 \\
Other disease & 4 & 13.3 \\
Physical trauma & 3 & 10.0 \\
\hline
\end{tabular}

with clinical signs of locoism were observed, but could not subsequently be found for further examination or necropsy. Addition ally, other elk were found dead, but the extended post-mortem interval made meaningful necropsies impossible.

All elk with clinical signs of locoweed poisoning were in or near riparian zones and open, wet meadows. This area represents $<5 \%$ of the available elk habitat on the ranch (Fig. 1). Most Oxytropis sericea at Vermejo Park grows within this same area.

Elk affected by locoweed poisoning were not observed with herds: they were solitary. Consistent clinical signs observed were emaciation, weakness, muscular trembling, incoordination, stumbling gait, lethargy, posterior ataxia, impairment of sensory perception, and rough haircoat. An unalarmed "locoed" elk generally stood with splayed front legs and "cow-hocked" hind legs. The head was usually lowered and the eyes had a blank stare. When they became aware of human presence, "locoed" elk generally panicked and ran aimlessly, crashing into trees, logs, fences, and other obstacles. Abortions were not observed. However, since abortions are difficult to document in free-ranging wildlife populations, they may have occurred undetected.

Gross morphologic changes consistently seen at necropsy were 
hydrothorax, hydroperitoneum, hydropericardium, serous atrophy of fat deposits, anemia, and cerebral edema. Other changes occasionally present were intermandibular edema, trauma wounds on the anterior aspect of the body, deformed antlers, granular appearance of the liver, oral ulceration, and ulceration of the pyloric portion of the abomasum.

Consistent histological changes were widespread cytoplasmic vacuolation in the parenchyma of most major organ systems. Most severely affected by cytoplasmic vacuolation were hepatocytes of the liver, acinar cells of the pancreas, reticuloendothelial cells of the spleen and lymph nodes, lining epithelium of the proximal convoluted tubules of the kidney, follicular cells of the thyroid gland and neurons throughout the central nervous system and mesenteric plexies.

Significant hematologic and serum chemistry changes observed in affected elk were depressed packed cell volume $(P<0.01)$, depressed hemoglobin $(P<0.01)$, depressed total protein $(P<0.001)$, elevated blood urea nitrogen $(P<0.05)$, elevated serum phosphorus $(P<0.001)$, and depressed serum calcium levels $(P<0.01)$ (Tables 4, 5).

Table 4. Blood parameters in normal elk collected at Vermejo Park, 1978. All elk were $<2$ years of age.

\begin{tabular}{llcc}
\hline \hline Parameter & $N$ & $\bar{x}$ & $\begin{array}{c}\mathrm{S}^{2} \\
\text { variance }\end{array}$ \\
\hline PCV, \% & 6 & 48.5 & 21.49 \\
Hb, gm \% & 6 & 18.9 & 3.00 \\
BUN, mg/dl & 6 & 19.8 & 47.86 \\
Phos, mg/dl & 6 & 4.4 & 2.13 \\
Ca, mg/dl & 6 & 10.5 & 0.15 \\
Total protein, g/dl & 6 & 6.8 & 0.09 \\
\hline
\end{tabular}

Table 5. Blood parameters in elk affected by locoweed poisoning at Vermejo Park. All elk were $<2$ years of age.

\begin{tabular}{lccc}
\hline \hline Parameter & $N$ & $\bar{x}$ & $\begin{array}{c}S^{2} \\
\text { variance }\end{array}$ \\
\hline PCV, \% & 5 & 26.1 & 167.37 \\
$\mathrm{Hb}, \mathrm{g} \%$ & 4 & 8.6 & 29.07 \\
$\mathrm{BUN}, \mathrm{mg} / \mathrm{dl}$ & 6 & 31.8 & 87.36 \\
$\mathrm{Phos}, \mathrm{mg} / \mathrm{dl}$ & 6 & 8.9 & 2.73 \\
$\mathrm{Ca}, \mathrm{mg} / \mathrm{dl}$ & 6 & 6.4 & 8.94 \\
Total protein, g/dl & 5 & 4.9 & 0.38 \\
\hline
\end{tabular}

Twelve (75\%) of the "locoed" elk were collected during 1978 (7 during March-May). None was observed during 1979 and 1980. Two each were collected in 1977 and 1981. The high incidence of locoweed poisoning observed in 1978 coincided with low January-April precipitation that year (Table 6).

Table 6. January-April precipitation at Vermejo Park ranch headquarters and number of "locoed" elk collected each year, 1976-81.

\begin{tabular}{lcc}
\hline \hline Year & $\begin{array}{c}\text { Precipitation } \\
(\mathrm{cm})\end{array}$ & $\begin{array}{c}N \text { of "locoed" elk } \\
\text { collected }\end{array}$ \\
\hline 1976 & 6.68 & 0 \\
1977 & 7.21 & 2 \\
1978 & 1.70 & 12 \\
1979 & 5.41 & 0 \\
1980 & 9.68 & 0 \\
1981 & 3.81 & 2 \\
\hline
\end{tabular}

Eleven (69\%) of the "locoed" elk were $<2$ years of age (Table 7). Aerial surveys indicated that approximately $39 \%$ of the herd was
Table 7. Sex and age distribution of 16 elk with clinical locoweed poisoning, Vermejo Park, 1977-81.

\begin{tabular}{lcccc}
\hline \hline & \multicolumn{3}{c}{ Age (yrs) } & \\
\cline { 2 - 4 } Sex & $<1$ & $1-2$ & $>2$ & Totals \\
\hline Male & 0 & 4 & 4 & 8 \\
Female & 6 & 1 & 1 & 8 \\
Totals & 6 & 5 & 5 & 16 \\
\hline
\end{tabular}

$<2$ years of age (Table 8 ). The number of young animals affected by locoweed poisoning was greater $(P<0.05)$ than would have been expected from the age structure of the population.

Table 8. Age distribution of 6,769 elk classified on aerial surveys at Vermejo Park, 1977-81.

\begin{tabular}{lcc}
\hline Age (yrs) & $N$ & $\%$ \\
\hline$<1$ & 1,564 & 23.1 \\
$1-2$ & 1,048 & 15.5 \\
$>2$ & 4,157 & 61.4 \\
\hline
\end{tabular}

Males and females were equally represented in the group of 16 "locoed" elk. However, all 6 of the affectd animals $<1$ year of age were females. Assuming a 50:50 sex ratio in elk $<1$ year of age, more $(P<0.05)$ juvenile females were affected than would have been expected. Eighty percent ( 8 of 10$)$ of the affected animals $>1$ year of age were males, but this was not significant $(P>0.05)$.

\section{Discussion}

Clinical signs, gross pathologic changes, and histologic lesions observed in the 16 "locoed" elk examined in this study are consistent with those described for livestock (James et al. 1967, 1968, 1969; Van Kampen and James 1969, 1971a) and the previously reported elk cases (Adcock and Keiss 1969). The degree to which elk in this study were habituated to locoweed can only be subjectively evaluated. Habituation is particularly common in domestic sheep grazing Oxytropis sericea (James 1972). Only 1 elk was actually observed eating locoweed; however, many clinically affected elk were observed in the same locoweed-infested locations for several days before being collected for examination.

The variation seen in individual elk as to the location and degree of cytoplasmic vacuolation of neurons and parenchymatous tissue is an expression of the stage of disease individuals were experiencing at the time of examination. Renal cytoplasmic vacuoles develop as early as $\mathbf{4}$ days following ingestion of locoweed and disappear within 7 days after removing locoweed from the diet (James and Van Kempen 1971b). Histological cytoplasmic vacuolation may be absent in most parenchymatous organs 30 days following removal of locoweed from the diet, although liver hepatocytes still retain significant cytoplasmic vacuolation beyond $\mathbf{3 0}$ days (Van Kampen and James 1972). Purkinje cells of the cerebellum may contain cytoplasmic vacuoles up to 1 year following locoweed poisoning (James and Van Kampen 1971b). The cerebellar folia also may have markedly decreased Purkinje cell numbers following locoweed poisoning (James and Van Kampen 1971b).

Hematologic and serum chemistry parameters of clinically affected elk in this study (Table 5) are significantly different from those reported for livestock with locoism and those of clinically normal elk of the same age-class from the Vermejo herd (Table 4). The low packed cell volume $(\bar{x}=26.1)$ and hemoglobin $(\bar{x}=8.6)$ indicate the severe degree of anemia in the "locoed" elk as compared to unaffected elk (PCV, $\bar{x}=48.5 ; \mathrm{Hb}, \bar{x}=18.9$ ). Reports concerning 
anemia in locoweed-poisoned animals are contradictory. Early reports list anemia as one of the consistently observed clinical signs of locoism (Crawford 1908, Marsh 1909). Adcock and Keiss (1969) reported that "pale blood" was occasionally observed in the "locoed" elk they examined. However, anemia has not been reported in recent literature as a consistent feature of spontaneous or experimental locoweed poisoning in domestic animals (James and Binns 1967, James et al. 1970). The elevated blood urea nitrogen (BUN) levels in affected elk $(\bar{x}=31.8)$ as compared to normal elk $(\bar{x}=19.8)$ may be an expression of rapid catabolic degradation of body proteins due to cachexia, rather than an indication of impaired renal function as suggested by James and Binns (1967). Only slightly elevated BUN levels have been reported in domestic sheep with experimentally induced locoweed poisoning (James and Binns 1967). The low total serum protein values of the "locoed" elk $(\bar{x}=4.9)$ compared to unaffected elk $(\bar{x}=6.9)$ are consistent with the clinical signs of intermandibular edema and accumulation of serous fluid in the body cavities. The aberrations observed in the serum calcium and phosphorus levels are possibly results of morphologic damage to the thyroid and parathyroid glands.

Increased prevalence of locoism in young animals has not been reported in either domestic or wild animals. The significantly higher prevalence of locoweed poisoning in elk $<2$ years of age may be related to inexperiened forage selection habits of young elk. Additionally, young cervids may finish the winter in poorer physical condition than adults and may have a more urgent physiological need for succulent green vegetation than mature animals. Although locoweed poisoning was more $(P<0.05)$ prevalent in female calves than male calves, we offer no explanation for this observation.

We believe the high prevalence of locoism observed in 1978 was an expression of poor range condition exacerbated by subnormal late winter - early spring precipitation (Table 6). The lack of adequate moisture delayed the initiation of new annual growth in most range plants. Locoweeds are among the first range plants to "green-up" at Vermejo Park. For several weeks during the spring of 1978 they were virtually the only green forage available. Due to the abundance of Oxytropis sericea and its proven toxicity (Kingsbury 1964:307; James et al. 1967, 1970; Van Kampen and James 1969), we believe it was the locoweed involved in the poisonings. In our opinion, Oxytropis lambertii and Astragalus spp. were not abundant enough to cause an outbreak of locoism.

Locoism has not been observed in livestock at Vermejo Park. Cattle are not moved into locoweed-infested areas until mid-May when adequate forage is available. Elk, however, use these areas continually during late winter and early spring.

Four "locoed" elk were examined between September and January. These elk probably became habituated during spring and continued to selectively graze locoweed throughout the summer and fall, although abundant alternative forage was readily available. It is also plausible that elk exhibiting clinical signs of locoism during the fall and winter may have suffered severe neurological damage due to the loss of Purkinje cells and other neurons during the original poisoning episode. This phenomenon has been observed in domestic sheep (James 1972).

In geographical areas where elk may be affected by elaeophorosis (Hibler and Adcock 1971), extra care must be taken to differentiate between these conditions as clinical signs are similar. Each produce emaciation, lethargy, clear-eyed blindness, incoordination, and abnormal antlers. Animals with elaeophorosis frequently have necrosis of the ear tips and muzzle. Elaeophorosis does not produce the widespread, severe cellular cytoplasmic vacuolation characteristic of locoism.

Although locoism has been confirmed in elk at Vermejo Park, we do not consider it to be a significant mortality factor in this herd. The distribution of most Oxytropis sericea at Vermejo Park represents $<5 \%$ of the available elk habitat on the ranch. Movement and distribution studies indicate that most elk at Vermejo
Park are in locoweed-free areas during the critical early spring period (Wolfe, unpubl. data).

Since "locoed" elk are physically impaired, we hypothesize that they are restricted to habitats with food and water in close proximity, such as wet meadows and riparian zones. Because of lack of cover, affected elk are easily located in these habitats. We do not claim to have identified all elk affected by locoism during the 5 -year period. However, due to the consistency with which individual "locoed" elk could be repeatedly located, we feel most of the severely affected elk were observed.

\section{Management Implications}

An outbreak of locoweed poisoning in an elk herd may indicate that changes in herd or range management practices are necessary. It may be an expression of excessive numbers of animals on the range during the low point of the nutrition year (February-March). Since environmental conditions contribute to the periodic growth habits of locoweed, outbreaks of locoweed poisoning occur sporadically (James et al. 1967). Unseasonably low late winter -early spring precipitation may delay the emergence of high quality forage and exacerbate a potential locoweed toxicity problem.

Locoweed poisoning may affect the population dynamics of an elk herd in several ways:

1. direct mortality of affected individuals due to locoweed toxicosis,

2. physical and sensory impairment which predispose affected individuals to other mortality agents such as predation and accidents, and

3. reproductive disorders resulting in abortion, birth defects, birth of undersized calves, and infertility.

Direct mortality may be readily observed and can be quite spectacular. Reproductive disorders caused by locoism are difficult to assess in free-ranging elk herds, but may impact herd population dynamics more significantly than direct mortality of individual animals. Abortion rates of up to $75 \%$ have been reported in domestic sheep herds grazing ranges heavily infested with locoweed (James et al. 1967). High rates of congenital deformities and birth of weak, undersized lambs have been documented in field studies and experimental feeding trials (James et al. 1967, 1969; Van Kampen and James 1971b). The toxin in locoweed can be secreted in the milk of ewes eating locoweed and has produced clinical signs of locoism in nursing lambs (James and Hartley 1977). It has been observed under field conditions that rams grazing locoweed may cease sexual activity (Shupe et al. 1968). In experimental feeding trials, cellular damage in the ram's reproductive tract was severe enough to impair reproduction, although it was not verified by breeding studies (James and Van Kampen 1971a). None of the reproductive disorders documented in domestic sheep has been reported in elk. However, based on the similarity of clinical signs, gross pathology, and histological lesions seen in both species, reproductive disorders could occur in elk populations grazing locoweed-infested ranges. This should be verified by experimental feeding trials. It is unlikely that locoweed poisoning could detrimentally impact elk herds occupying extensive ranges; however, populations restricted to ranges severely infested with locoweed may be significantly affected by reproductive disorders due to locoism. If low calf crops, low recruitment, or sick and incoordinated elk are reported from areas where locoweed grows, managers should consider the possibility of locoweed poisoning.

If locoweed poisoning is suspected, accurate observations of clinical signs and range conditions should be made. A thorough necropsy is important. Special attention should be given to the brain, carotid arteries (site of lesions characteristic of elaeophorosis), thyroid glands, lymph nodes, adrenal glands, liver, kidneys, pancreas, lungs, and heart. Tissue samples should be promptly placed in 10\% neutral buffered formalin for histological examination. Blood samples should be collected for hematology and serum chemistry. Rumen and fecal samples should be collected and pre- 
served for examination for evidence of Oxytropis spp., Astragalus spp., or other poisonous plants.

\section{Literature Cited}

Adcock, J.L., and R.E. Keiss. 1969. Locoism in elk. Bull. Wildl. Dis. Ass. 5:121-124.

Barker, E.S. 1976. Ramblings in the field of conservation. Sunstone Press, Santa Fe, N.Mex.

Buechner, H.K. 1950. Life history, ecology, and range use of the pronghorn antelope in Trans-Pecos Texas. Amer. Midl. Natur. 43:257-354.

Crawford, A.C. 1908. Barium, a cause of the locoweed disease. USDA, Bur. Plant Industry Bull. 129.

Hailey, T.L., J.W. Thomas, and R.M. Robinson. 1966. Pronghorn die-off in Trans-Pecos Texas. J. Wildl. Manage. 30:488-496.

Hibler, C.P., and J.L. Adcock. 1971. Elaeophorosis. J.W. Davis, and R.C. Anderson, eds. p. 263-278. In: Parasitic diseases of wild mammals. Iowa State Univ. Press, Ames.

James, L.F. 1972. Syndromes of locoweed poisoning. Clin. Tox. 5:567-573.

James, L.F., K.L. Bennett, K.G. Parker, R.F. Keeler, W. Binns, and B. Lindsay. 1968. Loco plant poisoning in sheep. J. Range Manage. $21: 360-365$.

James, L.F., and W. Binns. 1967. Blood changes associated with locoweed poisoning. Amer. J. Vet. Res. 28:1107-1110.

James, L.F., and W.J. Hartley. 1977. Effects of milk from animals fed locoweed on kittens, calves, and lambs. Amer. J. Vet. Res. 38:1263-1265.

James, L.F., R.F. Keeler, and W. Binns. 1969. Sequence in the abortive and teratogenic effects of locoweed fed to sheep. Amer. J. Vet. Res. 30:377-380.

James, L.F., J.L. Shupe, W. Binns, and R.F. Keeler. 1967. Abortive and teratogenic effects of locoweed on sheep and cattle. Amer. J. Vet. Res. 28:1379-1388.

James, L.F., K.R. Van Kampen, and G.R.Staker. 1969. Locoweed (Astragalus lentiginosus) poisoning in cattle and horses. J. Amer. Vet. Med. Ass. 155:525-530.

James, L.F., K.R. Van Kampen, and A.E. Johnson. 1970. Physiopathologic changes in locoweed poisoning of livestock. Amer. J. Vet. Res. 31:663-672.

James, L.F. and K.R. Van Kampen. 1971a. Acute and residual lesions of coweed poisoning in cattle and horses, J. Amer. Vet. Med. Ass. 158:614-618.

James, L.F. and K.R. Van Kampen, 1971b. Effects of locoweed intoxication on the genital tract of the ram. Amer. J. Vet. Res. 32:1253-1256.

Kingsbury, J.M. 1964. Poisonous plants of the United States and Canada. Prentice-Hall, Inc. Englewood Cliffs, N.J,

Küchler, A.W. 1964. Potential natural vegetation of the conterminous United States. Amer. Geo. Soc. Spec. Pub. 36.

Marsh, C.D. 1909. The locoweed disease of the plains. USDA, Bur. Anim. Industry Bull. 112.

Molyneux, R.J., and L.F. James. 1982. Loco intoxication: indolizidine alkaloids of spotted locoweeds (Astragalus lentiginosus). Science. 216:190191

Ogilvie, S. 1955. Chokecherry toxic to an antelope. J. Mammal. 36:146.

Shupe, J.L., L.F. James, K. Hoffman, and W. Binns. 1968. The effect of loco plant on libido and fertility in rams. Cornell Vet. 58:59-66.

Van Kampen, K.R. and L.F. James. 1969. Pathology of locoweed poisoning in sheep. Path. Vet. 6:413-423.

Van Kampen, K.R. and L.F. James. 1971a. Ophthalmic lesions in locoweed poisoning of cattle, sheep, and horses. Amer. J. Vet. Res. 32:1293-1295.

Van Kampen, K.R. and L.F. James. 1971b. Ovarian and placental lesions in sheep from ingesting locoweed (Astragalus lentiginosis). Vet. Path. 8:193-199.

Van Kampen, K.R. and L.F. James. 1972. Sequential development of lesions in locoweed poisoning. Clin. Tox. 5:575-580.

Van Kampen, K.R., R.W. Rhees, and L.F. James. 1978. Locoweed poisoning in the United States. R.F. Keeler, K.R. Van Kampen, and L.F. James, eds., p. 465-471. In: Effects of poisonous plants in livestock. Academic Press. New York, N.Y.

Williams, E.S. 1979. Unpubl. data. Wild Animal Disease Center, Colorado State University, Fort Collins.

Wolfe, G.J.1977. Goals and procedures of wildlife management on a large western ranch. Trans. North Amer. Wildl. and Natur. Resour. Conf. 42:271-277.

Wolfe, G.J. 1980. Elk management on a New Mexico ranch. W. Macgregor, ed. p. 26-32. In: Proc. west. states elk workshop. B.C. Fish and Wildl. Branch, Victoria.

Wolfe, G.J., A.A. Kocan, T.R. Thedford, and S.J. Barron. 1982. Hematologic and serum chemical values of adult female rocky mountain elk from New Mexico and Oklahoma. J. Wildl. Dis. 18:223-227.

CHANGE OF ADDRESS notices should be sent to the Managing Editor, 2760 West Fifth Ave., Denver, Colo. 80204, no later than the first day of the month of issue. Copies lost due to change of address cannot be replaced unless adequate notice is given. To assure uninterrupted service, provide your local postmaster with a Change of Address Order (POD Form 3575) indicating thereon to guarantee forwarding postage for second-class mail. 